Article

\title{
Equality of What? The Capability Approach and the Right to Education for Persons with Disabilities
}

\author{
Andrea Broderick \\ Department of International and European Law, Maastricht University, 6211 LH Maastricht, The Netherlands; \\ E-Mail: andrea.broderick@maastrichtuniversity.nl
}

Submitted: 29 September 2017 | Accepted: 27 December 2017 | Published: 26 March 2018

\begin{abstract}
The right to education is indispensable in unlocking other substantive human rights and in ensuring full and equal participation of persons with disabilities in mainstream society. The cornerstone of Article 24 of the United Nations Convention on the Rights of Persons with Disabilities seeks to ensure access to inclusive education for persons with disabilities on an equal basis with others as well as the full development of human potential. Since the adoption of the Convention, there has been much theorising about inclusive education; however, there has been little focus on the meaning of equality in the context of the right to education for persons with disabilities. The capability approach, developed by Amartya Sen and further refined by Martha Nussbaum, focuses on ensuring equality and developing human potential. It is often viewed as a tool that can be used to overcome the limitations of traditional equality assessments in the educational sphere, which only measure resources and outcomes. This article explores whether the capability approach can offer new insights into the vision of educational equality contained in the Convention and how that vision can be implemented at the national level.
\end{abstract}

\section{Keywords}

capability approach; CRPD; disability; education; equality; inclusive education; United Nations

\section{Issue}

This article is part of the issue "Disability Equality: In Theory and Practice", edited by Mark Priestley (University of Leeds, UK) and Lisa Waddington (Maastricht University, The Netherlands).

(C) 2018 by the author; licensee Cogitatio (Lisbon, Portugal). This article is licensed under a Creative Commons Attribution 4.0 International License (CC BY).

\section{Introduction}

The question 'equality of what?' is often posed during debates on political philosophy and interdisciplinary debates on distributive justice. It concerns a decision as to the elements which governmental policies and institutional structures should aim to equalise. The same question was posed by economist-philosopher Amartya Sen, who first introduced his theory of 'basic capability equality' in his Tanner Lectures (Sen, 1979, p. 218):

I believe what is at issue is the interpretation of needs in the form of basic capabilities. This interpretation of needs and interests is often implicit in the demand for equality. This type of equality I shall call "basic capability equality".
The capability approach encompasses a 'partial theory of social justice' (Nussbaum, 2009, p. 232) and a normative framework for the assessment of human development. In the last decade, scholars in the field of education studies have turned to the capability approach to analyse the theory and provision of education for those with special needs and/or disabilities (see, among others, Ainscow \& Farrell, 2002; Florian, Dee, \& Devecchi, 2008; Nind, Rix, Sheehy, \& Simmons, 2005). Several scholars have written about inclusive education, with a particular focus on capabilities (see, among others, Norwich, 2014; Robeyns, 2003, 2006; Rogers, 2013; Saito, 2003; Sarojini Hart, 2012; Terzi, 2005, 2007, 2014; Toson, Burrello, \& Knollman, 2013; Trani, Bakhshi, Ballanca, Biggeri, \& Marchetta, 2011; Walker, 2006a; Walker \& Unterhalter, 2007). Other scholars (Arnardóttir, 2011; Broderick, 
2014; Broderick \& Quinlivan, 2017; De Beco, 2014, 2016; Della Fina, 2017; Waddington \& Toepke, 2014) have addressed the right to education in Article 24 of the United Nations Convention on the Rights of Persons with Disabilities (CRPD or Convention). However, to date, there is scant research on the parallels between the capability approach and Article 24 CRPD (see, De Beco, 2017).

This article demonstrates that many of the underlying premises of the capability approach correlate to those contained in Article 24 CRPD. As a result, this article proposes a four-part framework, detailing insights into the vision of educational equality contained in the Convention through focussing on 'the what'; 'the why'; 'the who' and 'the how' of inclusive education. The first limb of the framework ('the what') outlines how capability equality can be invoked to shed light on the meaning of equality espoused by Article 24 CRPD. The second limb of the framework ('the why') draws on the underlying goals of inclusive education to outline the most relevant capabilities to be developed through inclusive education. The third limb of the framework ('the who') is drawn on to extract information on where to set the focus lens of inclusion. This can reveal invaluable lessons regarding pedagogical and assessment processes. The fourth limb of the framework ('the how') reveals how the inclusion of all learners can potentially be achieved through the mechanism of Universal Design for Learning (UDL). After outlining the aforementioned four-part framework, attention is paid to how that framework can be implemented at the national level.

This article is divided into seven sections. Following this first introductory section, the second section of the article outlines the key elements of the capability approach. The third section introduces Article 24 CRPD, focussing on the goals of inclusive education as well as the measures required to achieve inclusion. In section four of the article, a four-part framework is put forward, which outlines the vision of educational equality contained in Article 24 CRPD and highlights essential focal points for achieving inclusive education. Section five traces the theory of that framework into practice, while section six analyses whether the capability approach provides a complete guide to CRPD implementation. Finally, section seven presents concluding remarks.

The methodology used to highlight the salient features of the capability approach consists of descriptive desk-based research based on secondary sources. In analysing the obligations contained in Article 24 CRPD and inspiring the aforementioned four-part framework, legal doctrinal research is conducted. Recourse is had to the rules of treaty interpretation contained in the Vienna Convention on the Law of Treaties (VCLT). The interpretative tools in Articles 31 and 32 VCLT are as follows: literal interpretation according to the words contained in the text of the CRPD; systematic interpretation of the Convention's text in its overall context, including subsequent practice-namely, General Comments of the UN Committee on the Rights of Persons with Disabilities (CRPD
Committee); teleological interpretation according to the object and purpose of the Convention; and supplementary means of interpretation in line with the drafting history of the Convention (Ad-Hoc CRPD Committee, 2005). A comparative normative approach is used in drawing out the aspects of convergence between Article 24 CRPD and the capability approach. It is worth noting that the selection of capabilities for the above-mentioned fourpart framework is inspired by the norms and general principles underlying the CRPD as a whole and, in particular, those contained in Article 24. The case study examples that are used to illustrate the translation of inclusive education into practice are drawn from a selection of secondary sources highlighting best practice in the field.

\section{The Capability Approach}

In outlining his capability approach, Sen argued that neither utilitarian equality nor total utility equality nor Rawlsian equality sufficiently capture real differences amongst human beings (Sen, 1979, pp. 215-219), since the agents in such theories are generally deemed to be free, equal and independent beings. The capability approach, on the other hand, acknowledges that society is made up of individuals with unequal abilities and needs and, therefore, its basic underlying premise facilitates its application to disability studies. Sen's capability approach has been refined by philosopher Martha Nussbaum, among others. The relevant distinctions between Sen and Nussbaum's approaches are highlighted below.

The first basic conceptual distinction within the framework of the capability approach is between capabilities, on the one hand, and functionings and resources, on the other hand. Capabilities represent not the actual physical or mental ability of individuals but rather the innate potential of each individual to achieve various outcomes, defined as 'what people are actually able to do and to be' (Nussbaum, 2000, p. 5) when given real opportunities. Functionings represent various states of 'doings and beings' (Sen, 1992, p. 40), resulting in a particular outcome or achievement (reading, writing, communication, etc.), while 'resources' are the means by which to achieve the outcome. The capability approach highlights several 'conversion factors' (Sen, 1992, p. 100), such as environmental factors and social norms. These 'contribute to the determination of the individual capability set' (Trani et al., 2011, p. 152) and may affect the rate of conversion of resources into functionings. In the disability context, this mirrors the social-contextual perspective on disability, whereby disability is viewed as an interaction between individual impairments and the environment, attitudinal barriers, etc. (preamble, para. e CRPD).

Human diversity plays a key role in the capability approach since, according to Sen, it is 'a fundamental aspect of our interest in equality' (Sen, 1992, p. xi). Each individual forms a focal point of capability equality, according to Nussbaum (Nussbaum, 2000, p. 69). In that 
vein, Reindal asserts that 'it is not the group or changes of systems that are the primary subject of political justice' (Reindal, 2016, p. 8).

Central to Sen's capability approach are concepts of 'agency freedom' and 'wellbeing freedom'. The former refers to 'one's freedom to bring about achievements one values', while the latter relates to 'one's freedom to achieve those things that are constitutive of one's well being' (Sen, 1992, p. 57). According to Sen, the space within which to evaluate equality is that of capabilities, where an individual can decide what kind of life he/she values (Sen, 1992, p. 66).

Unlike Sen, who did not define universal capabilities, Nussbaum drafted a list of 'central human capabilities' as a benchmark for setting a 'social minimum' (Nussbaum, 2009 , p. 232), a threshold level below which a just society seeking to guarantee the key principle of human dignity should not fall. Nussbaum's list of central human capabilities includes: life; bodily health; bodily integrity; the senses, imagination and thought; emotions; play; other species; and control (political and material) over one's environment (Nussbaum, 2000, pp. 78-80). Nussbaum points to two further capabilities, which she argues 'suffuse all the other capabilities' (Nussbaum, 2000, p. 89): i) 'practical reason', which involves 'being able to form a conception of the good and to engage in critical reflection about the planning of one's life'; and ii) affiliation, which means being able to engage in various forms of social interactions [and] being able to be treated as [a] dignified being whose worth is equal to that of others' (Nussbaum, 2000, pp. 79-80).

Norwich states that the fundamental distinction between Sen and Nussbaum's approaches lies in the fact that 'for Sen, agency is the key aspect of a capability', while for Nussbaum, 'the central capabilities are more an entitlement than something actively chosen' (Norwich, 2014, p. 19). Despite these differences, one can conclude that the pivotal assessment of equality under the capability approach lies not necessarily in an assessment of the means provided to an individual or the functionings achieved by that individual but in the equalisation of opportunities to develop one's innate capabilities. In the disability sphere, the equality metric is based on counteracting the impact of impairment in individualised situations and nurturing whatever capabilities each individual has in order to enable human flourishing.

Saito points to the 'potentially strong and mutually enhancing relationship' between the capability approach and education (Saito, 2003, p. 17). Several authors appear to pick up on that potential. For instance, Sarojini Hart contends that the capability approach 'offers an alternative paradigm for thinking beyond access to education and for considering the potential for individual freedoms both in and through education' (Sarojini Hart, 2012, p. 276; see also, De Beco, 2017; Rajapakse, 2016; Reindal, 2016, p. 6).

There is an absence of scholarship on the overlapping elements of the capability approach and Article 24 CRPD (see De Beco, 2017). Thus, it is an opportune time to explore whether the tenets of the capability approach align with the fundamental premises of inclusive education set out in Article 24 and whether the capability approach can be drawn on to reveal specific lessons regarding the norms contained in Article 24

\section{Article 24 CRPD: A Holistic Vision of Inclusive Education}

Article 24 CRPD enshrines the first legal enunciation of inclusive education for all learners. The following subsections elaborate on the goals of inclusive education and the measures required to achieve inclusion.

\subsection{The Goals of Inclusive Education}

On a textual reading of the CRPD, the overarching theme of Article 24 is that education must be effective. Article 24(2)(d) provides that States Parties must ensure that 'persons with disabilities receive the support required, within the general education system, to facilitate their effective education'. This begs the question as to what effectiveness means as a metric in this context?

According to the text of Article 24(1), inclusive education systems should ensure 'the full development of human potential and sense of dignity and self-worth' and 'the strengthening of respect for...human diversity'. Furthermore, education systems must aim at the 'development by persons with disabilities of their personality, talents and creativity, as well as their mental and physical abilities, to their fullest potential'. These stated goals of inclusive education clearly overlap, to a significant extent, with the fundamental tenets of the capability approach.

The third goal to be achieved by inclusive education, as laid down in Article 24(1), is to enable 'persons with disabilities to participate effectively in a free society'. This defines the ultimate purpose of inclusive education and seeks to ensure that all measures adopted by States Parties to the Convention contribute to facilitating that purpose. Terzi contends that a capability perspective on educational equality can be defined 'in terms of equal effective opportunities to levels of functionings that are necessary to participate in society' (Terzi, 2007, p. 765). In a similar vein, one can deduce from the text of Article 24 that States Parties are required to create real opportunities for persons with disabilities to foster their capabilities in order to enable them to take an active role in society, where possible.

\subsection{The Measures Required to Achieve Inclusion}

In order to achieve the foregoing goals, Article 24 CRPD sets down an extensive list of obligations to be complied with by States Parties, the most relevant of which are outlined below. The measures required under Article 24 are based on the social-contextual model of disability, which 
targets disadvantages arising from the interaction between learners' impairments and external factors caused by environmental or attitudinal barriers to learning. Article 24 is also built on the human rights-based model of disability, according to which persons with disabilities are viewed as individual 'holders of rights, entitled to exercise all human rights and fundamental freedoms on an equal basis with others, entailing the provision of material support where necessary' (Broderick, 2015, p. 1).

Article 24 seeks to ensure equality of access to all levels of education (primary, secondary and tertiary education as well as vocational training, adult education and lifelong learning) and the provision of equal opportunities. Maintaining a similar focus on individualisation as the capability approach does, Article 24 CRPD seeks to address the wide diversity of needs of individual learners through requiring States Parties to take various positive measures. In that regard, Article 24(2)(c) requires States Parties to ensure that reasonable accommodation of the individual learner's requirements is provided. Reasonable accommodation, as defined in Article 2 CRPD, requires public and private parties to make 'necessary and appropriate modification and adjustments' to the environment, where requested by an individual with a disability in a particular case. An unjustified failure to provide a reasonable accommodation constitutes a form of discrimination, unless a disproportionate or undue burden can be proven by the duty-bearer.

Further individualised support measures are envisaged under Article 24(2)(e) CRPD. The latter measures are not the same as those requested in a particular, individualised case; conversely, they aim to alter the mainstream education system to ensure inclusion over a longer period of time (de Beco, 2014, p. 281). This does not mean that these measures do not have to be tailored to cater for the individual needs of each learner (de Beco, 2014, p. 281). Such individualised support measures may include personal assistance as well as the types of measures outlined in Article 24(3) CRPD, namely, facilitating the learning of Braille; providing alternative script; augmentative and alternative modes, means and formats of communication; and facilitating peer support and mentoring.

Akin to Nussbaum's list of central capabilities (endorsing practical reason and affiliation as well as emotions and play), Articles 24(2)(e) and 24(3), respectively, acknowledge the fact that education is not merely an academic tool. Rather, education should 'enable persons with disabilities to learn life and social development skills to facilitate their full and equal participation in education and as members of the community'. To that end, States Parties must take appropriate measures to ensure that the education of persons with disabilities (and, in particular, individuals who are blind, deaf or deaf-blind) is delivered in the most appropriate languages and means of communication for the individual, and in environments which maximise academic and social development.

\section{Inclusive Education Viewed through the Lens of the Capability Approach}

It is evident that there are prima facie similarities between the capability approach and the vision of inclusive education set forth in Article 24 CRPD. This section of the article investigates whether, beyond those prima facie similarities, the capability approach can serve to teach States Parties to the CRPD specific lessons regarding the norms embodied in Article 24. The key observations emerging from the analysis conducted in this section are set out in a four-part framework and are aligned with 'the what', 'the why', 'the who' and 'the how' of inclusive education. These four parts of the framework relate back to the understanding of equality enshrined in Article 24 CRPD (as interpreted according to the methodological tools set out in the first section of this article).

\section{1. 'The What' of Inclusion: Equality of Capabilities}

The first limb of the four-part framework concerns 'the what' of inclusion. The capability approach purports that equality is measured in the realm of capabilities, such that the central factor in the search for justice relates to equalising opportunities for expanding an individual's capabilities (but not necessarily equalising outcomes). Capability equality lays down human diversity as the key equalising element in the evaluation of relative disadvantages and the fight against inequalities. Due to the fact that the capability approach is underpinned by respect for human diversity, it is equipped to deal with 'the complexity of disability' (Terzi, 2005, p. 452). This justifies invoking it to shed light on the meaning of equality espoused by Article 24 CRPD. The fact that the capability approach also adopts a social-contextual approach, much like the CRPD, means that it endorses a similar egalitarian perspective, according to which entitlement to equal opportunities arises regardless of the fact that disadvantage may accrue from impairment or external factors (Terzi, 2005, p. 452). Overall, it can be said that there is 'general agreement on the essential underlying ideas' of the capability approach and the CRPD (Harnacke, 2013, p. 777). Notwithstanding this, many questions remain unanswered as to whether the capability approach can act as a guide to CRPD implementation. These questions will be highlighted and answered in turn in the sub-sections that follow.

\section{2. 'The Why' of Inclusion: The Purpose of Article 24 and Equalisation of Capabilities}

One naturally wonders which capabilities should be equalised in the educational context? In order to answer that question and to build on the equality metric, it is important to take into account the underlying goals of inclusive education, highlighted above. This leads us to reflect on 'the why' of inclusion, the second limb of the four-part framework proposed in this paper. 
Various authors have followed Nussbaum's example and have devised lists of 'basic capabilities' in the educational context (Mutanga \& Walker, 2015, pp. 505-506; Walker, 2006b, pp. 128-129). Others have devised lists of basic capabilities which are not tailored to education but which overlap with educational capabilities (Robeyns, 2003). However, none of these lists have been tailored specifically towards inclusive education and learners with disabilities. Drawing on CRPD-specific values and informed by the principles underlying the capability approach, it is submitted that the following capabilities encapsulate the most relevant ones to be developed through inclusive education for all learners:

i. Academic skills (knowledge): Article 24 CRPD requires that school systems foster academic development. In this context, academic skills would take into account critical thinking and problem-solving skills, promoting the knowledge required for participation in society and the economy. Depending on the severity of disability, the level of functioning following from this capability of knowledge will, inevitably, vary. However, the basic capability for knowledge should be fostered in all students. Indeed, evidence suggests that students with psychosocial and developmental disabilities can learn to problem-solve in an inclusive setting through modifications to social and communication processes (Agran, Blanchard, Wehmeyer, \& Hughes, 2002, p. 279).

ii. Life and social development skills: The CRPD also requires the development of life and social skills. The capability approach requires that informal learning should be taken into consideration. This has been defined as a space where 'relationships and encounters' occur, 'with all the opportunities that are planned and unplanned' (European Agency for Development in Special Needs Education, 2011, p. 104).

iii. Individual autonomy, including the freedom to make one's own choices, and independence: Article 3(a) CRPD contains the cross-cutting general principle of individual autonomy, including the freedom to make one's own choices, and independence. Drawing on that Article, it is submitted that learner agency and autonomy should be promoted in all individuals. This autonomy capability does not find support in Nussbaum's account of capability equality. As Stein points out, Nussbaum's earlier work 'excludes certain persons with intellectual disabilities from full participation in society' (Stein, 2007, p. 102), as she 'fails to recognize those who fall below her ten central capabilities' (Stein, 2007, p. 101). According to Stein, Nussbaum's capability approach only includes persons with intellectual disabilities who are able to achieve baseline functions 'by proxy through their respective guardians' and this 'denies their individual auton- omy' (Stein, 2007, pp. 109-110). In her later work, Nussbaum appears to adopt a similar perspective in the realm of cognitive disabilities (see, Nussbaum, 2009, pp. 345-350). To overcome these issues, Stein proposes a 'disability human rights paradigm', which 'emphasizes the equal dignity of all persons, and acknowledges their autonomy in directing their own development'. (Stein, 2007, p. 75). Stein's approach fits well to the autonomy capability proposed in this article. Although, when it comes to operationalising the autonomy capability in the context of young learners, this will naturally depend on support from adults. With regard to individuals with multiple disabilities or severe intellectual/learning/behavioural disabilities, promoting independence and autonomy becomes a more complex task. This point is dealt with below.

iv. Respect for evolving capacities: Drawing on key CRPD principles, in particular General Principle $3(\mathrm{~h})$, which recognises the evolving capacities of children with disabilities, it is essential to nurture the preferences of persons with disabilities and to foster in them the capacity to make informed and reflexive choices, wherever possible. When it comes to individuals with severe or multiple disabilities, one of the main challenges lies in overcoming the perception that such individuals cannot exercise self-determination on account of the nature or extent of their impairment (Wehmeyer, 1998). The CRPD Committee urges States Parties to avoid this 'deficit approach', which focuses on the 'actual or perceived impairment' of a person with a disability and which limits opportunities 'to predefined and negative assumptions of their potential' (CRPD Committee, 2016, para. 16). Assessing the preferences of students with severe learning difficulties through alternative modes, means and formats of communication is something which Article 24(3)(a) CRPD expressly urges. Several strategies have been identified to determine the preferences of students with severe disabilities, such as, using micro-switch technology to enable students to indicate preferences; observing whether students approach an object when it is presented to them; and recording the amount of free time a student spends engaged in particular activities (Hughes, Pitkin, \& Lorden, 1998).

v. Respect for inherent dignity: Nussbaum's later work claims that 'the touchstone' of capability equality is human dignity (Nussbaum, 2009, p. 335). Pursuant to Articles 3(a), 3(d) and 8(2)(b) CRPD, States Parties should foster in all children, from an early age, respect for the inherent dignity of all learners and the acceptance of difference.

vi. Voice and participation in learning: In accordance with Articles 4(3) and 7(3) CRPD, States Parties should ensure that all learners, particularly those with disabilities, are enabled to develop the capa- 
bility to express their views freely on educational matters affecting them and to participate actively in knowledge acquisition.

vii. Identity preservation: Drawing on Articles 24(3)(b) and 24(4)(4) CRPD, inclusive education systems should prioritise the capability for learners with disabilities to preserve their individual identities and to develop them in whatever way suits their learning style. This is particularly important for students who are deaf, blind and/or deaf-blind.

viii. Self-worth: Nussbaum claims that capability equality guarantees the 'social bases of self-respect and non-humiliation' (Nussbaum, 2000, p. 79). In accordance with Article 24(1)(a) CRPD, inclusive education systems should foster capabilities of selfesteem in all learners in order to avoid the issue of what Nussbaum terms 'adaptive preferences' (Nussbaum, 2000, p. 139), whereby individuals adapt their preferences according to what they believe is feasible for their 'perceived' capabilities.

While the above list does not constitute an exhaustive enumeration of inclusive education capabilities, it does provide a good starting point in seeking to ensure equality of educational opportunities for all and in framing education systems which facilitate the underlying principles and goals of the CRPD.

\section{3. 'The Who' of Inclusion: Individuals as an End}

The capability approach also informs us about where to set the focus lens of inclusion - in other words, the third limb of the proposed framework, which centres on the who' of inclusion. This can reveal invaluable lessons regarding pedagogical and assessment processes.

Since capability equality targets individuals, the goal, in educational terms, is to produce capabilities for each and every learner. Nussbaum refers, in this connection, to the fact that each person is 'an end' (Nussbaum, 2011, p. 35). While capability equality focuses pivotally on human individuality, it also focuses on interdependency (Nussbaum's criterion of affiliation). This vision of inclusion matches that set forth in Article 24 CRPD, which not only focuses on system changes but mandates the adoption of reasonable accommodations and effective individualised supports for persons with disabilities.

The person-centred approach underpinning Article 24 has been remarked upon by the CRPD Committee:

Inclusive education must aim at promoting mutual respect and value for all persons and at building educational environments in which the approach to learning, the culture of the educational institution and the curriculum itself reflect the value of diversity (CRPD Committee, 2012, para. 41).

This requires both the recognition of difference and offering general mainstream provision for all learners. The next sub-section of this article elaborates on how to achieve this delicate balance by elaborating on the fourth limb of the proposed framework - 'the how' of inclusion, that is, its processes and practices.

\section{4. 'The How' of Inclusion: The Dilemma of Difference Re-Visited through UDL}

Several educational scholars are divided by the 'dilemma of difference' (Minow, 1990, p. 20) and tend to focus almost exclusively on either impairment (Mac Kay, 2002) or social processes (Armstrong, Armstrong, \& Barton, 2000). The 'dilemma of difference' is a term used to describe the tensions inherent in focusing, on the one hand, on differential characteristics, with the attendant risks of stereotyping and labelling, and, on the other hand, ignoring differences in an attempt to provide common educational provision, bearing the risk that not all learners' needs are accommodated.

Terzi argues cogently that the capability approach manages to erase the tensions inherent in the dilemma of difference, since it allows overcoming 'the duality between individual and social models of disability and sees disability instead as inherently relational' (Terzi, 2005, p. 451). It is here that the capability approach finds particular resonance with the CRPD, which also overcomes these tensions (Broderick, 2015, p. 72).

From an equality perspective, both the capability approach and the CRPD seek to widen the 'norm' in order to reflect human diversity and individual difference, whilst also ensuring education in the mainstream. This widened norm can be given concrete formulation in the mechanism of UDL, a curriculum-based method designed to achieve maximum accessibility of educational processes for all. While implementing UDL is not without significant challenges, the ideas of differentiated instruction and 'alternative functionings' (Terzi, 2005, p. 456), or of doing the same thing in different ways, takes on increased relevance in this context. According to the CRPD Committee, this involves 'flexible curricula and teaching and learning methods adapted to different strengths, requirements and learning styles' (CRPD Committee, 2016, para. 12.c). It also entails 'maintaining high expectations for all students while allowing for multiple ways to meet expectations' (CRPD Committee, 2016, para. 26).

Since diversity in education refers not only to the diversity of needs exhibited by persons with disabilities but to the entire range of different learning abilities, needs, talents, learning styles and personalities, it is vital to link these wide-ranging considerations to key goals and outcomes to be achieved by the educational curriculum. Knowelton (1998) suggests three levels of curricular modification necessary to enhance access for all to mainstream curricula: i) curriculum adaptation (modifying the presentation and representation of content); ii) curricular augmentation (teaching students to use studentdirected learning strategies); and iii) curriculum alteration (changing the curriculum to address students' spe- 
cific needs). In that regard, the CRPD Committee recommends the use of individual educational plans (IEPs) to support specific learning requirements and the introduction of a pedagogy centred on students' educational objectives. (CRPD Committee, 2016, para. 71).

Authors, such as De Beco, acknowledge the fact that there are 'practical limits to differentiation in the school curriculum' and that 'education systems may never be completely adaptable to the needs of all disabled children' (De Beco, 2017, p. 10). These concerns regarding the implementation of inclusive education and universal design in learning are entirely valid, and it may be the case that a fully universal design is simply not achievable due to wide variations in impairments. Nonetheless, the ideal of inclusive education remains a worthy goal, and the capability approach certainly lends itself to teaching us valuable lessons in the quest to realise inclusion.

\section{Capability Equality: From Theory to Practice in Inclusive Education}

Having outlined the four-part framework above, a framework that may be used to guide pedagogical and assessment process in implementing the CRPD, it is important to reflect on the practical relevance of the above framework in the provision of public inclusive education.

In rejecting a de minimus standard for the education of persons with disabilities, the Supreme Court of the United States recently held, in Endrew F. v. Douglas County School District, that every child's educational program must be 'appropriately ambitious in light of his circumstances' and that children with disabilities should have the chance to 'meet challenging objectives' (Endrew, 2017, p. 3). One might wonder how this can be achieved in the light of the framework outlined above?

As a preliminary step, the CRPD's vision of educational equality should be enshrined in States Parties' laws and policies in order to guide educational processes. Italian law specifically includes the development of the potential of persons with disabilities 'in learning, in communication, in relationships and in socialisation' in Articles 12 and 13 of Law 104/1992 ${ }^{1}$ (Ferri, in press). Decree $378 / 2017$, implementing Law $107 / 2015{ }^{2}$ which is aimed at reforming the Italian educational system following ratification of the CRPD, also promotes 'educational and teaching strategies aimed at developing the potential of each individual', according to Ferri (in press).

Practical changes to school systems are also required in order to promote the key capabilities outlined above in the context of the four-part framework. Ensuring that persons with disabilities are appropriately challenged in public education and, furthermore, balancing that with the needs of children without disabilities requires a reciprocal approach. Jorgensen et al. advocate peer supports, whereby students have the opportunity to provide sup- port and assistance to others as well as to receive support (Jorgensen, Mc Sheehan, Schuh, \& Sonnenmeier, 2012, p. 7). The European Agency for Development in Special Needs Education advocates such co-operative learning or peer tutoring as an effective method in cognitive and affective (social-emotional) learning and development for all students (European Agency for Development in Special Needs Education, 2003, p. 5). As well as enhancing academic and social development skills, this type of approach can serve to enhance the capabilities of respect for diversity, evolving capacities of persons with disabilities and self-worth. Mixed-age classes (the joint education of children with heterogeneous abilities from pre-school to the fourth grade) have been advocated in certain countries, such as Austria and Finland, as a means to incorporate diverse learning rates in primary school classes. While there are certainly many challenges inherent in effectuating such an approach (Hyry-Beihammer \& Hascher, 2015), it has been promoted as one that can have 'obvious' benefits at the cognitive, emotional and social levels (European Agency for Development in Special Needs Education, 2003, p. 29).

Person-centred planning aids greatly in achieving the key capabilities of self-determination, learner autonomy and participation. A Danish project, entitled 'Children's Voice', consults with parents and children to elicit their views on the well-being and experiences of each learner (UNESCO, 2017, p. 28). Involving students in the formulation of learning objectives is an effective means by which to include all students in their own learning processes. In that regard, Jorgensen et al. promote the teaching of self-advocacy skills-'how to be assertive, how to effectively communicate their perspective, how to negotiate, how to compromise, and how to deal with systems and bureaucracies' (Jorgensen et al., 2012, p. 11).

Evaluation and assessment processes should also be a key focus for States Parties. The framework outlined in section four of this article sheds light on four vital aspects of the inclusion process ('the what'; 'the why'; 'the who' and 'the how' of inclusion) and allows for the assessment of inequalities in a space other than that used for traditional equality measurements in the educational sphere, which often focus on resources and outcomes. That space is the realm of capabilities. The measurement that is used to determine whether each individual is granted equal opportunity to flourish stems from an assessment of the starting point of the individual and his/her progress towards defined and overarching goals within the mainstream curriculum, combined with the individualised goals set out in his/her IEP, designed to map personal successes. The CRPD Committee appears to agree with this perspective on how human potential can be facilitated through assessment processes. The Committee has stated that 'traditional systems of assessment, which use standardized achievement test scores as the

\footnotetext{
${ }^{1}$ Law of 5 February 1992 No. 104, 'Legge-quadro per l'assistenza, l'integrazione sociale e i diritti delle persone handicappate' in O.J. of 17 February 1992 No. 39.

2 In O.J. No.162 of 15 July 2015.
} 
sole indicator of success for both students and schools' (CRPD Committee, 2016, para. 74), 'must be replaced with flexible and multiple forms of assessments and the recognition of individual progress towards broad goals that provide alternative routes for learning' (CRPD Committee, 2016, para. 26). Jorgensen et al. recommend implementing an evaluation system whereby students receive grades that are reflective of 'personal best' achievements.

Connecting education systems more closely to the key capability of life development skills is also essential for ensuring real inclusion. In Spain, the project Your Education Has No Limits: Develop Your Future advocates awareness-raising campaigns targeted at promoting the active participation of secondary school-level individuals with disabilities in universities and in the workforce. Jorgensen et al. encourage the incorporation of annual goals in students' IEPs that not only reflect common core state standards but 'functional skills necessary for full participation in school and life in the community after high school' (Jorgensen et al., 2012, p. 3). Portuguese Decree Law $3 / 2008^{3}$ goes even further than that to establish a framework for the transition process from school to employment for learners with severe intellectual disabilities (aged 15 or over). According to the European Agency for Special Needs and Inclusive Education (n.d.), the first phase of each Individual Transition Plan (ITP) is to reveal 'the wishes, interests, aspirations and competencies' of each individual. A subsequent phase of the ITP includes an assessment of the gaps in the local job market and the identification of training opportunities or internships for the individual. These are then matched to the academic, personal and social competencies of the individual, and required adjustments and special equipment are documented. Agreements are then set up with the relevant institutions, defining the competencies required for the position, the tasks to be carried out and the support needed to achieve those tasks.

Having reflected on how the capability approach inspires a four-part framework to guide educational processes and how it can teach States Parties lessons in implementing the vision of equal educational opportunities set out in Article 24 CRPD, it is apt to consider whether the capability approach can provide a complete guide to CRPD implementation?

\section{The Capability Approach: A Complete Guide to CRPD Implementation?}

Given that it is not possible to realise all rights at once, a complete guide to CRPD implementation should also guide States Parties on issues of prioritisation and distribution of resources. Harnacke argues that, 'due to an insufficient grounding of the capabilities which makes a hierarchy among the various capabilities impossible', the capability approach cannot fulfil this role (Harnacke, 2013 , p. 777). Terzi (2007, p. 770) claims that other theories, such as Rawlsian theories on 'justice as fairness'
(Rawls, 2001), need to be drawn on in order to guide this element of CRPD implementation.

Other limitations to the capability model have been identified by scholars. According to Nussbaum herself, the capability approach is a 'social-minimum approach' (Nussbaum, 2011, p. 40). Therefore, it is incomplete, since it does not make any 'commitment about how inequalities above the minimum ought to be handled' (Nussbaum, 2011, p. 40). Additionally, Norwich questions whether it is really possible to determine what counts as adequate functioning (Norwich, 2014, p. 19).

The four-part framework set out in section four of this article does not claim to solve these (arguably substantial) limitations and does not constitute a full theory of educational equality. It simply focuses on the development of capabilities as a key to guiding processes and practices in education rather than measuring functioning as the sole end goal. The effectiveness of educational systems is often measured relative to means and result. In view of the constraints associated with focusing only on resources and outcomes, this article has argued that it is pivotal to redefine the values underpinning education systems and the capability sets that are developed through education, not only for persons with disabilities but for all learners. A list of educational capabilities has, therefore, been extrapolated in this article and is set out as the second limb of the proposed framework above. It is based on key CRPD values. The proposed list of educational capabilities and the fourpart framework may prove useful in answering a range of equality-related questions, including whether certain individuals are accorded more opportunities than others to convert resources into functionings. In that sense, this article demonstrates the human and social development aspect of education rather than simply the 'dominant neoliberal human capital interpretations of education as only for economic productivity and employment' (Walker, 2006a, p. 164).

The capability approach inspires a normative ethical framework and rationale for the provision of inclusive education, while the CRPD fleshes out the legal framework associated with ensuring that the goals of inclusive education are met. Reading them together provides a key to unlocking equality of opportunities for many students.

Outcomes cannot be ignored, of course, and the use of indicators for monitoring CRPD rights is an essential compliment to any approach based on capabilities. The CRPD Committee requires States Parties to develop monitoring frameworks with structural indicators (to measure barriers) and process indictors (to measure changes to the accessibility of physical environments, curriculum adaptations and teacher training), with specific benchmarks and targets attached to each indicator (CRPD Committee, 2016, para. 75). The four-part framework outlined in this article can go some way towards highlighting and solving structural and process issues in education. Nonetheless, the individualised focus of the ca-

\footnotetext{
${ }^{3}$ Decreto-Lei n.o 3/2008, de 7 de Janeiro.
} 
pability approach proves ineffective in addressing the broader issues related to CRPD implementation, as highlighted above.

During the drafting process of General Comment 4 of the CRPD Committee (on inclusive education), it was acknowledged that 'no reliable and comparable data is available' on access to education and learning outcomes for children and adult learners with intellectual disabilities, in particular (Inclusion Netherlands, 2016). In view of such deficiencies, the Committee requires States Parties to develop outcome indicators, measuring the percentage of students with disabilities in inclusive learning environments obtaining final official certification or diplomas (CRPD Committee, 2016, para. 75). Since effective participation in society is the end goal to be achieved in implementing Article 24 CRPD, and since some individuals with disabilities never manage to attain even a basic level of functioning in society, these elements of CRPD implementation certainly cannot be neglected. The capability approach does not provide much guidance in that respect. Indeed, De Beco argues that the capability approach 'does not explain whether...participation is a goal in itself or just a means to enhance capabilities' (De Beco, 2017, p. 14).

\section{Conclusion}

According to Sen, the question 'equality of what?' is pivotal in the search for justice. As demonstrated in this article, the capability approach inspires a four-part framework based upon justice and equality of capabilities. It advocates that social structures should respond to human diversity and allow for human flourishing.

In a similar vein to capability equality, the CRPD is based on respect for the inherent dignity of persons with disabilities, individual autonomy, including the freedom to make one's own choices; respect for difference and acceptance of persons with disabilities as part of human diversity. All of these values underpin the vision of educational equality of opportunity that Article 24 CRPD sets forth. Article 24 seeks to ensure accessible, individualised educational systems, tailored to the wide diversity of needs and innate capabilities of learners with disabilities.

In attempting to theorise equality in education, this article has drawn on the parallels between the values espoused by Article 24 CRPD and the capability approach in order to delineate a four-part framework for inclusion. In doing so, this article demonstrates how the capability approach provides a useful metric for examining inequalities. This can teach us invaluable lessons regarding the processes and practices of inclusive education. It is submitted that the vision of equality set forth in Article 24 can be strengthened if a focus is maintained in the implementation process on the 'the what', 'the why', 'the who' and 'the how' of inclusion.

These four limbs of the proposed framework shed light on learning processes, on the social value of educa- tion, on the key focal points of inclusion as well as on the role of educational structures in perpetuating or mitigating inequalities. While the capability approach has several limitations in terms of guiding inclusion and can only inspire a partial framework for CRPD implementation, this partial framework is nonetheless useful in guiding educational processes, policies and institutions towards a more holistic definition of equal opportunities.

The language of capabilities is not exclusive to disability studies, and the lessons learned from the interface between Article 24 CRPD and the capability approach can be applied to the provision of inclusive education for all individuals. This can help to ensure that each individual reaches his/her full potential and can go some way towards ensuring full and equal participation in education for persons with disabilities and as members of the community, just as Article 24 itself requires.

\section{Acknowledgments}

The author would like to thank the two anonymous reviewers who provided most helpful and insightful comments on the draft of this article.

\section{Conflict of Interests}

The author declares no conflict of interests.

\section{References}

Ad-Hoc CRPD Committee. (2005). Travaux préparatoires. Retrieved from www.un.org/esa/socdev/enable/ rights/adhoccom.htm

Agran, M., Blanchard, C., Wehmeyer, M., \& Hughes, C. (2002). Increasing the problem-solving skills of students with developmental disabilities participating in general education. Remedial and Special Education, 23(5), 279-288.

Ainscow, M., \& Farrell, P. (2002). Making special education inclusive: From research to practice (1st ed.). London: David Fulton Publishers.

Armstrong, D., Armstrong, F., \& Barton, L. (2000). Inclusive education: Policy, contexts and comparative perspectives. London: David Fulton Publishers.

Arnardóttir, O. M. (2011). The right to inclusive education for children with disabilities - Innovations in the CRPD. In A. Eide, J. Möller, \& I. Ziemele (Eds.), Making peoples heard: Essays on human rights in honour of Gudmundur Alfredsson (pp. 197-227). Leiden: Martinus Nijhoff Publishers.

Broderick, A. (2014). The right to inclusive education: Article 24 of the UN Convention on the Rights of Persons with Disabilities and the Irish experience. Irish Yearbook of International Law, 9(1), 25-60.

Broderick, A. (2015). The long and winding road to equality and inclusion: The United Nations Convention on the Rights of Persons with Disabilities. Antwerp: Intersentia. 
Broderick, A., \& Quinlivan, S. (2017). The right to education: Article 24 of the CRPD. In C. O' Mahony, \& G. Quinn (Eds.), The UN Convention on the Rights of Persons with Disabilities: Comparative, regional and thematic perspectives (pp. 293-208) Dublin: Clarus Press.

Committee on the Rights of Persons with Disabilities. (2012). Concluding observations of the Committee on the Rights of Persons with Disabilities, Hungary, U.N. Doc CRPD/C/HUN/CO/1.

Committee on the Rights of Persons with Disabilities. (2016). General Comment 4, UN Doc. CRPD/C/GC/4.

De Beco, G. (2014). The right to inclusive education according to Article 24 of the UN Convention on the Rights of Persons with Disabilities: Background, requirements and (remaining) questions. Netherlands Quarterly of Human Rights, 32(3), 263-287.

De Beco, G. (2016). Transition to inclusive education systems according to the Convention on the Rights of Persons with Disabilities. Nordic Journal of Human Rights, 34(1), 40-59.

De Beco, G. (2017). The right to inclusive education: Why is there so much opposition to its implementation? International Journal of Law in Context, 1-20.

Della Fina, V. (2017). Article 24 CRPD (education). In V. Della Fina, R. Cera, \& G. Palmisano (Eds.), The United Nations Convention on the Rights of Persons with Disabilities: A commentary (pp. 439-470). Cham: Springer Publications.

Endrew F. v. Douglas County School Dist. RE-1, No. 15827, 580 U.S. (2017).

European Agency for Development in Special Needs Education. (2011). Participation in inclusive education: a framework for developing indicators. Retrieved from https://www.european-agency.org/sites/default/files /participation-in-inclusive-education-a-frameworkfor-developing-indicators_Participation-in-InclusiveEducation.pdf

European Agency for Development in Special Needs Education. (2003). Inclusive education and effective classroom practices. Retrieved from https://www. european-agency.org/sites/default/files/inclusiveeducation-and-effective-classroom-practice_IECP-Lit erature-Review.pdf

European Agency for Special Needs and Inclusive Education. (n.d.). Portugal-Overview. Retrieved from https://www.european-agency.org/country-informa tion/portugal/national-overview/complete-nationaloverview

Ferri, D. (in press). The past, present and future of the right to inclusive education in Italy. In S. Quinlivan, G. De Beco, \& J. Lord, The right to inclusive education in international human rights law. Cambridge: Cambridge University Press.

Florian, L., Dee, L., \& Devecchi, C. (2008). How can the capability approach contribute to understanding provision for people with learning difficulties? Prospero, 14(1), 24-33.
Harnacke, C. (2013). Disability and capability: Exploring the usefulness of Martha Nussbaum's capabilities approach for the UN disability rights Convention. Journal of Law, Medicine \& Ethics, 41(4), 768-780.

Hughes, C., Pitkin, S., \& Lorden, S. (1998). Assessing preferences and choices of persons with severe and profound mental retardation. Education and Training in Mental Retardation and Developmental Disabilities, 33(4), 299-316.

Hyry-Beihammer, E. K., \& Hascher, T. (2015). Multigrade teaching practices in Austrian and Finnish primary schools. International Journal of Educational Research, 74(1), 104-113.

Inclusion Netherlands. (2016). Submission to draft General Comment 24 of the Committee on the Rights of Persons with Disabilities. Retrieved from http:// www.ohchr.org/EN/HRBodies/CRPD/Pages/GCRight Education.aspx

Jorgensen, C. M., Mc Sheehan, M., Schuh, M., \& Sonnenmeier, R. M. (2012). Essential best practices in inclusive education. Durham: National Center on Inclusive Education Institute on Disability, University of New Hampshire. Retrieved from http://www.tash.org/wpcontent/uploads/2011/03/Essential-Best-Practices070312-FULL-Jorgensen.pdf

Knowelton, E. (1998). Considerations in the design of personalized curricular supports for students with developmental disabilities. Education and Training in Mental Retardation and Developmental Disabilities, 33(2), 95-107.

Mac Kay, G. (2002). The disappearance of disability? Thoughts on a changing culture. British Journal of Special Education, 29(4), 151-163.

Minow, M. (1990). Making all the difference: Inclusion, exclusion and American law. New York: Cornell University Press.

Mutanga, O., \& Walker, M. (2015). Towards a disabilityinclusive higher education policy through the capabilities approach. Journal of Human Development and Capabilities, 16(4), 501-517.

Nind, M., Rix, J., Sheehy, K., \& Simmons, K. (2005). Curriculum and pedagogy in inclusive education: Values and practice. London: Routledge.

Norwich, B. (2014). How does the capability approach address current issues in special educational needs, disability and inclusive education field? Journal of Research in Special Educational Needs, 14(1), 16-21.

Nussbaum, M. C. (2000). Women and human development: The capabilities approach (1st ed.). Cambridge: Cambridge University Press.

Nussbaum, M. (2009). The capabilities of people with cognitive disabilities. Metaphilosophy, 40(3/4), 331-351.

Nussbaum, M. C. (2011). Creating capabilities: The human development approach (1st ed.). Cambridge: Cambridge University Press.

Rajapakse, N. (2016). Amartya Sen's capability approach and education: Enhancing social justice. Revue LISA. 
Retrieved from https://lisa.revues.org/8913

Rawls, J. (2001). Justice as fairness: A restatement (1st ed.). Cambridge: Harvard University Press.

Reindal, S. M. (2016). Discussing inclusive education: An inquiry into different interpretations and a search for ethical aspects of inclusion using the capabilities approach. European Journal of Special Needs Education, 31(1), 1-12.

Robeyns, I. (2003). Sen's capability approach and gender inequality: Selecting relevant capabilities. Feminist Economics, 9(2/3), 61-91.

Robeyns, I. (2006). Three models of education: Rights, capabilities and human capital. Theory and Research in Education, 4(1), 69-84.

Rogers, C. (2013). Inclusive education and intellectual disability: A sociological engagement with Martha Nussbaum. International Journal of Inclusive Education, 17(9), 988-1002.

Saito, M. (2003). Amartya Sen's capability approach to education: A critical exploration. Journal of Philosophy of Education, 37(1), 17-33.

Sarojini Hart, C. (2012). The capability approach and education. Cambridge Journal of Education, 42(3), 275-282.

Sen, A. (1979). Equality of what? Retrieved from http:// tannerlectures.utah.edu/_documents/a-to-z/s/sen 80.pdf

Sen, A. (1992). Inequality re-examined (1st ed.). Oxford: Oxford University Press.

Stein, M. A. (2007). Disability human rights. California Law Review, 95(1), 75-122.

Terzi, L. (2005). Beyond the dilemma of difference: The capability approach to disability and special educational needs. Journal of Philosophy of Education, 39(3), 443-459.

Terzi, L. (2007). Capability and educational equality: The just distribution of resources to students with disabilities and special educational needs. Journal of Philos- ophy of Education, 41(4), 757-773.

Terzi, L. (2014). Reframing inclusive education: Educational equality as capability equality. Cambridge Journal of Education, 44(4), 479-493.

Toson, A. L., Burrello, L. C., \& Knollman, G. (2013). Educational justice for all: The capability approach and inclusive education leadership. International Journal of Inclusive Education, 17(5), 490-506.

Trani, J. F., Bakhshi, P., Ballanca, N., Biggeri, M., \& Marchetta, F. (2011). Disabilities through the capability approach lens: Implications for public policies. ALTER-European Journal of Disability Research/Revue Européenne de Recherche sur le Handicap, 5(3), 143-157.

UNESCO. (2017). A guide for ensuring inclusion and equity in education. Retrieved from http://unesdoc. unesco.org/images/0024/002482/248254e.pdf

Waddington, L., \& Toepke, C. (2014). Moving towards inclusive education as a human right: An analysis of international legal obligations to implement inclusive education in law and policy. Maastricht Faculty of Law Working Paper No. 2014-7. Retrieved from https://ssrn.com/abstract $=2535198$

Walker, M. (2006a). Towards a capability-based theory of social justice for education policy-making. Journal of Education Policy, 21(2), 163-185.

Walker, M. (2006b). Higher education pedagogies: $A$ capabilities approach. Maidenhead: Society for Research on Higher Education/Open University Press and McGraw-Hill.

Walker, M., \& Unterhalter, E. (2007). Sen's capability approach and social justice in education (1st ed.). New York: Palgrave Macmillan.

Wehmeyer, M. L. (1998). Self-determination and individuals with significant disabilities: Examining meanings and misinterpretations. Journal of the Association for Persons with Severe Handicaps, 23(1), 5-16.

\section{About the Author}

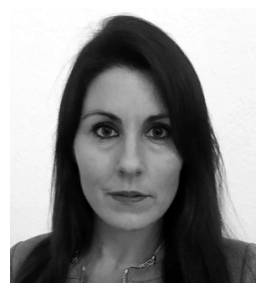

Andrea Broderick (PhD) is a tenured Assistant Professor in the Department of International and European Law at the Faculty of Law, Maastricht University. Andrea previously completed a Marie Curie fellowship at Maastricht University in the DREAM (Disability Rights Expanding Accessible Markets) network of researchers. Her doctoral thesis on the CRPD's equality norm was nominated for the Max van der Stoel Human Rights Award (2016) and has been published as a monograph with Intersentia. 